\title{
A Flex-market Design for Flexibility Services through DERs
}

Zhang, Chunyu; Ding, Yi; Østergaard, Jacob; Bindner, Henrik W.; Nordentoft, Niels Christian; Hansen, Lars Henrik; Brath, Poul; Cajar, Peder Dybdal

\section{Published in:}

Proceedings of IEEE ISGT Europe 2013

Publication date:

2013

Link back to DTU Orbit

Citation (APA):

Zhang, C., Ding, Y., Østergaard, J., Bindner, H. W., Nordentoft, N. C., Hansen, L. H., Brath, P., \& Cajar, P. D. (2013). A Flex-market Design for Flexibility Services through DERs. In Proceedings of IEEE ISGT Europe 2013 IEEE.

\section{General rights}

Copyright and moral rights for the publications made accessible in the public portal are retained by the authors and/or other copyright owners and it is a condition of accessing publications that users recognise and abide by the legal requirements associated with these rights.

- Users may download and print one copy of any publication from the public portal for the purpose of private study or research.

- You may not further distribute the material or use it for any profit-making activity or commercial gain

- You may freely distribute the URL identifying the publication in the public portal

If you believe that this document breaches copyright please contact us providing details, and we will remove access to the work immediately and investigate your claim 


\section{A Flex-market Design for Flexibility Services through DERs}

\author{
Chunyu Zhang, Yi Ding, Jacob \\ Østergaard, Henrik W. Bindner \\ Center for Electric Power and Energy \\ Technical University of Denmark \\ Copenhagen, Denmark
}

\author{
Niels Christian Nordentoft \\ Danish Energy Association \\ Copenhagen, Denmark
}

\author{
Lars Henrik Hansen, Poul Brath, \\ Peder Dybdal Cajar \\ DONG Energy \\ Copenhagen, Denmark
}

\begin{abstract}
The high penetration of distributed energy resources (DERs) will significantly challenge the power system operation due to their intermittent characteristic. In order to utilize the DERs as economically efficient as possible in the distribution grid, an Aggregator-based Flex-market is proposed in this paper. With the brand new notion of Flexibility Clearing House $(F L E C H)$, the proposed Flex-market has the ability to promote small scale DERs (up to 5MW) to participate in flexibility services trading. Accordingly, efforts to relieve the congestions in local grid areas, the contractual flexibility services of DERs are stipulated accommodating the various requirements of DSOs. The trading setups and processes are illustrated in details as well. Additionally, the demonstration diagram of Flex-market is also introduced in this paper. The diagram is utilized to test the feasibility and robustness of the market solutions.
\end{abstract}

Index Terms - electricity market; distributed energy resources (DERs); Aggregator; Flexibility Clearing House (FLECH); flexibility services

\section{INTRODUCTION}

In the future, the renewable energy (Wind, PV, etc.) and more efficient energy sources (CHP, HP, EV, etc.) are critically improving the security of energy supply by drawing upon sustainable natural sources and reducing environmental impacts [1-5]. The high penetration of distributed energy resources (DERs) is considerably observed worldwide. For instance, by 2020, the share of renewable energy in Denmark must be increased to at least $35 \%$ of final energy consumption - $50 \%$ of electricity consumption supplied by wind power [6].

These DERs will pose a significant challenge associated with balance and congestion issues due to their intermittent characteristic. The vast majority of previous and ongoing renewable energy sources and smart grid projects have focused on assessing the technical feasibility of DERs, which widely concern that the improvement and innovation on electricity markets will play an essential role on utilizing the DERs as economically efficient as possible.

Over the past decade, with the emerging new concept of Virtual Power Plant (VPP), people mainly emphasis on enabling DERs to participate in the existing market, especially to provide the ancillary service. The European Union (EU) project FENIX defines VPP as a flexible representation of a portfolio of DERs that can be used to make contracts in the wholesale market and to offer services to the system operator. There are two types of VPP, the Commercial VPP (CVPP) and the Technical VPP (TVPP). The CVPP is a competitive market actor that manages the DER portfolios to make optimal decisions on participation in wholesale markets. The TVPP aggregates and models the response characteristics of a system containing DERs, controllable loads and networks within a single grid [7]. In other words, the CVPP optimizes its portfolio with reference to the wholesale markets, and passes DER schedules and operating parameters to the TVPP. The TVPP uses input from the CVPPs operating in its area to manage any local network constraints and determine the characteristics of the entire local network at the Grid Supply Points (GSPs) [8].Thus, the role of TVPP in distribution networks is the same as the TSO's role in transmission systems.

However, this scope maybe not accurate for the future scenarios, because of the primary task of TSO is to avoid system-wide imbalance occurring, while the executive issue for DSOs is to relieve the congestions in local network. In addition, the size limitations are often cited as another big barrier for small scale DERs (up to 5MW) to access the wholesale market, e.g. 10MW in Nordpool market. Therefore, we have to pave a novel way to fully utilize the advantages of small scale DERs - Focusing on the distribution grid, proper coordination and activation of consumers and DERs will provide more flexibility in ancillary services, which can enhance efficiency and reliability of distribution system.

In this paper, an Aggregator-based Flex-market is proposed to give a shot for the feasibility of promoting small scale DERs to participate in flexibility services trading. With the new entity- FLECH, the proposed Flex-market will satisfy the DSOs' requirements of congestion management and facilitate the integration of DERs into power system. Meanwhile, the flexibility services provided by DERs will expand the properties of existing ancillary services, conducive 
to the security and stability of distribution even transmission system operation.

\section{FLEX-MARKET DESIGN}

The structure of proposed Flex-market and the interaction of the corresponding stakeholders are illustrated in Figure 1, depicted in the left portion of the dotted line. The Flex-market relies on designed Aggregators to provide flexibility services through DERs, which coexist with the existing market. Obviously, the Aggregator and Flexibility Clearing House $(F L E C H)$ are the brand new participants.

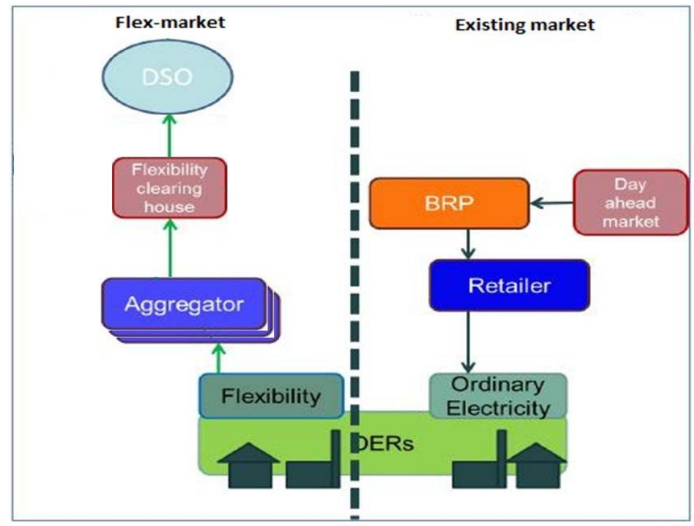

Figure 1. The structure of Flex-market

1) The Aggregator: which is a new commercial player, who has three basic functions:

- $\quad$ Aggregate and mobilize flexibility of DERs, pack it, and sell the services to the highest possible bidder with contract.

- Have thorough knowledge of the electricity markets, put the right price on the flexibility services, and represent DERs to trade in Flex-market.

- $\quad$ Paid by the DSOs for delivering flexibility services. From this payment the Aggregator will pay his affiliated DERs according to their contractual agreement.

2) The FLECH: which is an independent non-profit driven entity, also responsible for:

- The DSOs will make standardized contracts with Aggregators by stipulating service category in FLECH.

- Ensure the Flex-market integrity by mitigating counterparty default risk, and monitors the contracts are being carried out more targeted and efficiently.

- Provide clearing of all contracts traded on the exchange, a sort of ex post financial settlement.

It could be further observed that, in this concise and efficient market framework, the supplier is DERs while the consumer is DSO, which inverts the roles with the prevailing market. Correspondingly, the new features of Flex-market can be summarized briefly in TABLE I.
TABLE I.

THE NEW FEATURES OF FLEX-MARKET

\begin{tabular}{|c|c|}
\hline Factors & Flowability \\
\hline Capital & DSO $\rightarrow$ FLECH $\rightarrow$ Aggregator $\rightarrow$ DERs \\
\hline Power / Energy & DERs $\rightarrow$ Aggregator $\rightarrow$ DSO \\
\hline Control signal & DSO $\rightarrow$ Aggregator $\rightarrow$ DERs \\
\hline Commercial signal & DSO $\leftrightarrow F L E C H \leftrightarrow$ Aggregator $\leftrightarrow$ DERs \\
\hline Physical network & DERs $\rightarrow$ DSO \\
\hline
\end{tabular}

\section{TRADING}

\section{A. Trading Setups}

The core missions for FLECH are contracts regulation and ex post financial settlement, there are three possible trading setups are identified as:

1) Bilateral contracts: The negotiations between DSOs and Aggregators are through individual bilateral contracts. However, since only DSOs know exactly where and how much it desires flexibility services, the DSOs are expected to specify the services and present to the Aggregators they are negotiating with.

2) Auctions: With the increased volume in trading flexibility services, an auction-based setup will arise. The DSOs propose the request of flexibility services, and the costs in negotiations will be spared. Then, the Aggregators submit bids for satisfying the requested services of DSOs. Finally, the DSOs choose the available bids appropriately from the Aggregators, and standardized contracts are automatically formed according to the market-rules of FLECH.

3) Supermarkets: In opposite to the auctions, the Aggregators have the initiative in Supermarket setup. Considering the historical data, the Aggregators will be able to estimate where and how much the DSOs might be interested in buying the desired flexibility services. Then, the Aggregators could propose and price various services, just like in the "supermarket", the DSOs are the consumers of these flexibility services willing to select their favorite products.

These three trading setups do not necessarily replace each other, but will be a mutually beneficial co-existence according to their own merits.

\section{B. Trading Processes}

Take auction-based trading setup for instance, the trading processes are shown in Figure 2 and depicted as follows:

1) Posting and resposing process: As a part of the yearahead network planning at the DSOs, the possibility of using flexibility contracts will be considered. For the local grid areas, the DSOs can see substantial benefits in requiring a type of flexibility services, and then post their demands at FLECH with a deadline for Aggregators to submit bids. On the basis of this, offers will be clustered from interested Aggregators, and contracts are made.

2) Testing process: All of this will be done approximately on a year-ahead basis. Closing to the contractual period, the 
Aggregators' ability to deliver the contracted flexibility services could be tested.

3) Activating process: Finally, the contractual period will come and the DSO will activate flexibility services as specified in the contract, if necessary.

4) Clearing process: Since the contractual period has ended, settlement between the DSOs and the Aggregators will be carried out and the mutual contractual obligations have been completed.

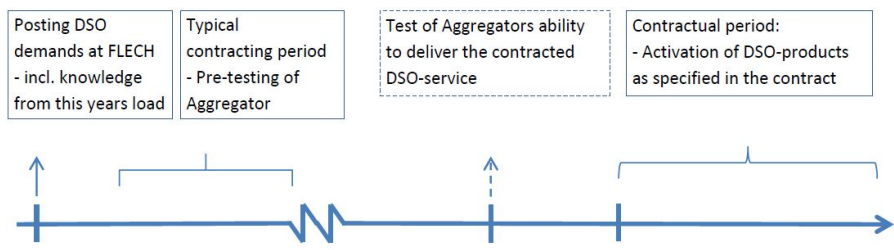

Dec. Jan.

Figure 2. The trading processes of Flex-market

\section{THE FLEXIBILITY SERVICES}

With the high penetration of DERs and rapid growth of smart grid projects, congestion becomes one of the most challenging operation issues in distribution network. Generally, the main congestion managements could be classified as follows:

1) Feeder overload: The high power flow over feeder capacity-limit, which may be caused by regular growth in electricity consumption, active reserve capacity in the grid, activation of regulating power for the TSO, very low prices of electricity.

2) Feeder voltage: The variations of voltage and issues of reactive power can be exceed the band of feeder deviation limits, which normally caused by local generations and demand.

Accordingly, aiming to explore new solutions for DSO's congestion managements, several contractual flexibility services offered by Aggregators are defined in this paper, listed in TABLE II.

TABLE II.

DER'S CONTRACTUAL FLEXIBILITY SERVICE

\begin{tabular}{|c|c|c|}
\hline \multirow{2}{*}{ Service } & \multicolumn{2}{|c|}{ Congestion management } \\
\cline { 2 - 3 } & Overload & Voltage \\
\hline PowerCut Planned & predictable peak load & - \\
\hline PowerCut Urgent & urgent regulation & - \\
\hline PowerReserve & reserve capacity & - \\
\hline PowerCap & capacity limits & - \\
\hline PowerMax & DERs limits & - \\
\hline VoltageSupport & - & deviation limits \\
\hline VarSupport & - & reactive power limits \\
\hline
\end{tabular}

\section{A. Overload Management}

In order to satisfy DSOs' requirements of feeder overload management, five types of flexibility services feasibly provided by Aggregators are defined in this paper, see solid lines in Figure 3-a) e), namely,

- PowerCut Planned is used to handle the predictable peak loads for periodically daily capacity issues, e.g. during the winter, the distributions grids usually experience the highest loads. If the hourly load patterns could be forecasted at each feeder, then the DSOs will desire the load reduction $(\Delta P)$ service from Aggregators hour-by-hour.

- PowerCut Urgent is an event-based flexibility service, which looks similar to PowerCut Planned, but will be less frequently activated every day during the contract period.

- PowerReserve will be able to exploit the new reservesupply within the limits of $70 \% \sim 100 \%$, on the perspective of DSOs. Moreover, in view of un-locking this expansion of available capacity, it is necessary to reduce loads when facing a reserve-supply situation. However, this sort of flexibility service will be rarely activated as it will only be served when a feeder get faulted plus the load exceeding the $70 \%$ capacity limit during the exactly hours of a year.

- PowerCap will pledge a feeder capacity limit specified by the DSOs will not be violated.

- PowerMax is suitable for the DSOs to make it clearly that the Aggregators obligate to guarantee their local portfolio will not exceed a certain quantity. Besides, the DSOs need to make qualified consumption prognosis of both managed and unmanaged loads, to alert unmanaged loads will not alter consumption pattern.

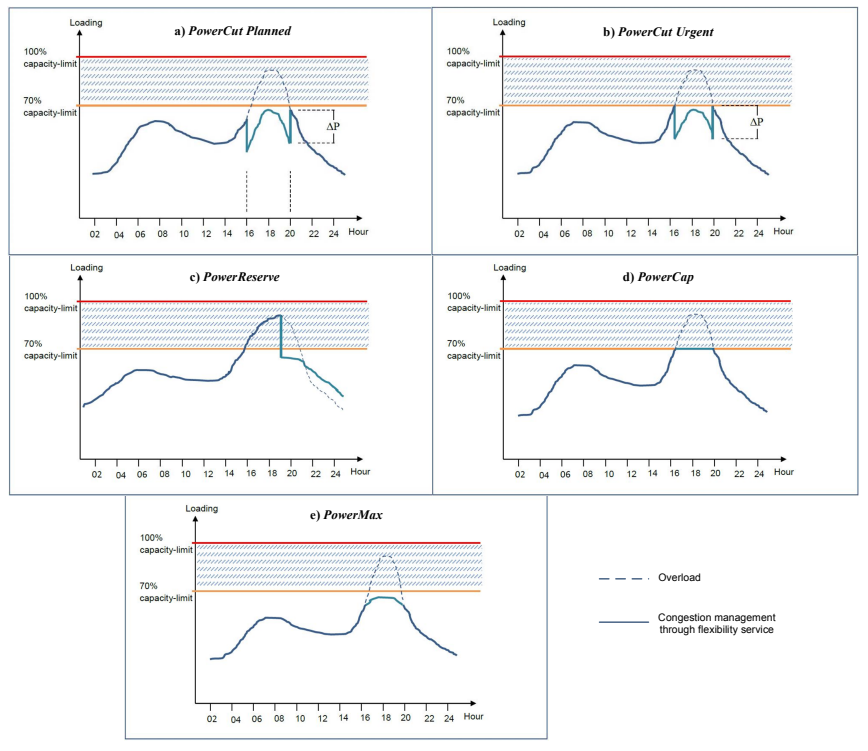

Figure 3. Flexibility services of Aggregators for overload management 


\section{B. Voltage Management}

In regard of serving the DSOs with voltage stability support, there are two flexibility services of Aggregators could offer to ensure that the respective feeders stay within a proper voltage band, e.g. $\pm 10 \%$.

- VoltageSupport will specified by DSOs in different voltage levels with the best knowledge of grid state, and the contracted Aggregators have to ensure these voltages will not beyond the limits.

- VarSupport mobilizes the Aggregators to cooperate with the reactive power control of DSOs, primarily for the voltage of transformers to be maintained in the particular limits. This flexibility service will reduce the expenses on purchasing shunt reactors or capacitor banks.

\section{Sample Application}

For each flexibility service, a set of contractual prerequisites should be explicitly stipulated to achieve an efficient and economic operation, including service duration, activations, location, trigger, price, risk and penalty statement, etc. Certain feeders in a $10 \mathrm{kV}$ distribution grid are taken for a sample to further illustrate the stipulations of these services, shown in TABLE III.

\section{DEMONSTRATION}

The Flex-market based Danish national project- iPower will be demonstrated in the near future, which has a large penetration and high diversity of DERs. 32 international partners will be involved in this project to test the feasibility and robustness of the proposed market solutions to several future scenarios.

The sequence diagram of this demonstration is illustrated in Figure 4

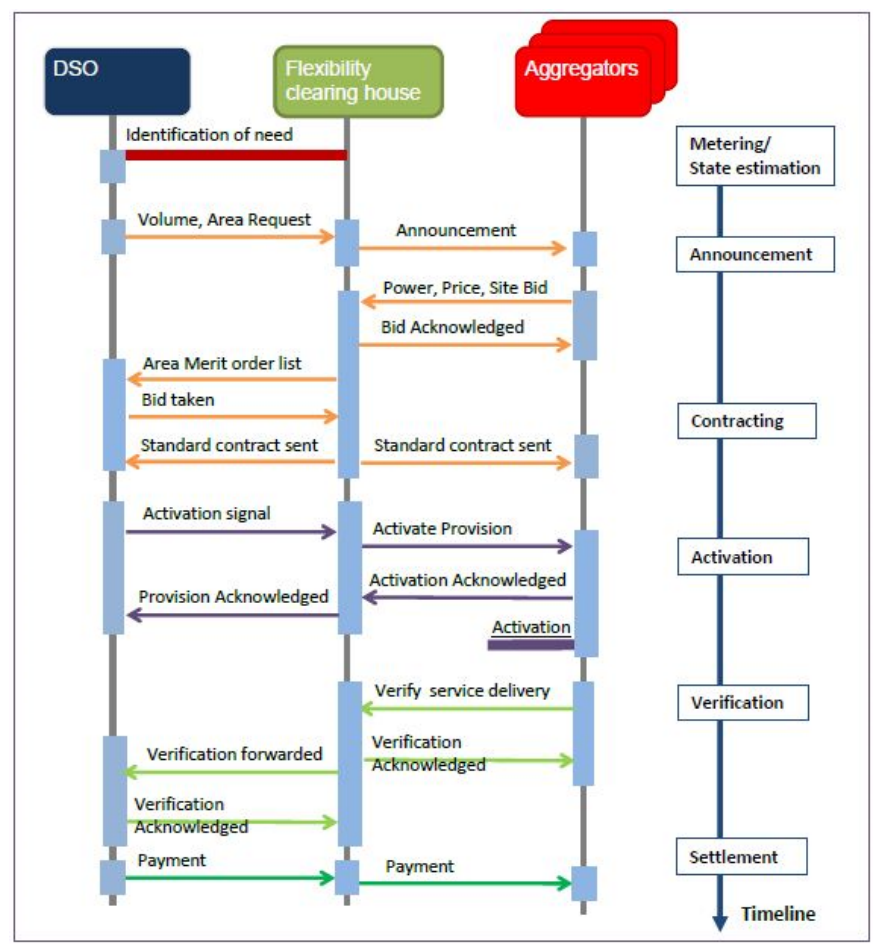

Figure 4. The sequence diagram of iPower project demonstration

TABLE III. THE SAMPLE OF FLEXIBILITY SERVICES STIPULATION

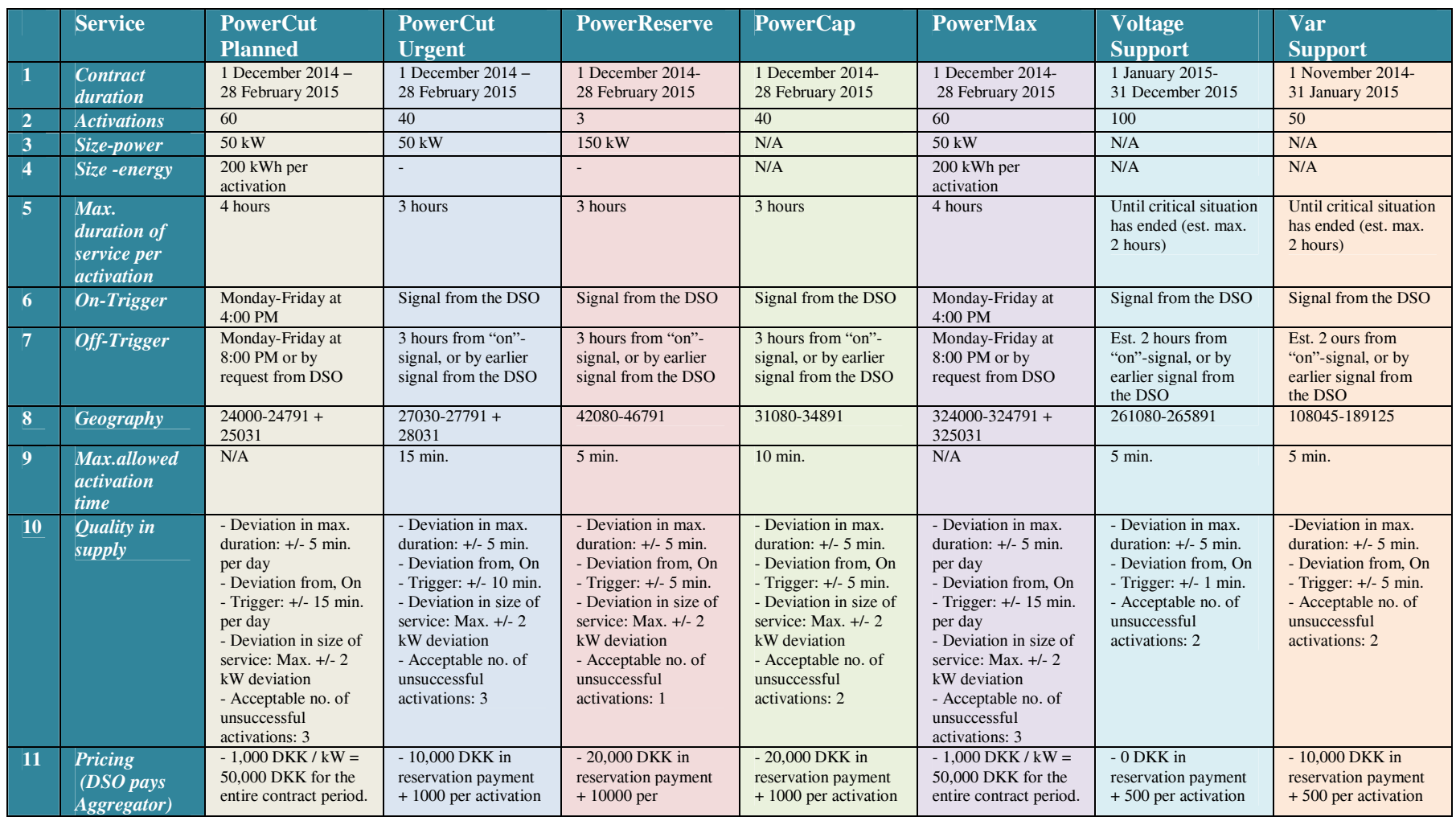




\begin{tabular}{|c|c|c|c|c|c|c|c|c|}
\hline & & $\begin{array}{l}\text { - Paid at the end of } \\
\text { the period, due to risk } \\
\text { of alternative } \\
\text { Aggregator ignorance } \\
\text { of the contract }\end{array}$ & $\begin{array}{l}\text { = estimated to } 40,000 \\
\text { DKK for the entire } \\
\text { contract period. } \\
\text { - In total } 50,000 \\
\text { DKK as maximum } \\
\text { payment for the } \\
\text { entire contract period. } \\
\text { - Paid at the end of } \\
\text { the period, due to risk } \\
\text { of alternative } \\
\text { Aggregator ignorance } \\
\text { of the contract }\end{array}$ & $\begin{array}{l}\text { activation }= \\
\text { estimated to } 30,000 \\
\text { DKK for the entire } \\
\text { contract period. } \\
\text { - In total } 50,000 \\
\text { DKK as maximum } \\
\text { payment for the } \\
\text { entire contract period. } \\
\text { - Paid at the end of } \\
\text { the period, due to risk } \\
\text { of alternative } \\
\text { Aggregator ignorance } \\
\text { of the contract }\end{array}$ & $\begin{array}{l}\text { = estimated to } 40,000 \\
\text { DKK for the entire } \\
\text { contract period. } \\
\text { - In total } 60,000 \\
\text { DKK as maximum } \\
\text { payment for the } \\
\text { entire contract period. } \\
\text { - Paid at the end of } \\
\text { the period, due to risk } \\
\text { of alternative } \\
\text { Aggregator ignorance } \\
\text { of the contract }\end{array}$ & $\begin{array}{l}\text { - Paid at the end of } \\
\text { the period, due to risk } \\
\text { of alternative } \\
\text { Aggregator ignorance } \\
\text { of the contract }\end{array}$ & $\begin{array}{l}\text { = estimated to } 50,000 \\
\text { DKK for the entire } \\
\text { contract period. } \\
\text { - In total } 50,000 \\
\text { DKK as maximum } \\
\text { payment for the } \\
\text { entire contract period. } \\
\text { - Paid at the end of } \\
\text { the period, due to risk } \\
\text { of alternative } \\
\text { Aggregator ignorance } \\
\text { of the contract }\end{array}$ & $\begin{array}{l}\text { = estimated to } 25,000 \\
\text { DKK for the entire } \\
\text { contract period. } \\
\text { - In total } 35,000 \\
\text { DKK as maximum } \\
\text { payment for the } \\
\text { entire contract period. } \\
\text { - Paid at the end of } \\
\text { the period, due to risk } \\
\text { of alternative } \\
\text { Aggregator ignorance } \\
\text { of the contract }\end{array}$ \\
\hline 12 & $\begin{array}{l}\text { Estimated } \\
\text { price per } \\
\text { activation }\end{array}$ & - 830 DKK & $-1,250$ DKK & - 16,700 DKK & $-1,500$ DKK & -830 DKK & $-500 \mathrm{DKK}$ & -500 DKK \\
\hline 13 & Risk issues & $\begin{array}{l}\text { Failure in supply, due } \\
\text { to: } \\
\text { - faulted } \\
\text { communications or } \\
\text { control systems } \\
\text { between Aggregator } \\
\text { and DERs }\end{array}$ & $\begin{array}{l}\text { Failure in supply, due } \\
\text { to: } \\
\text { - faulted } \\
\text { communications or } \\
\text { control systems } \\
\text { between Aggregator } \\
\text { and DERs } \\
\text { - Faulted } \\
\text { communication of } \\
\text { trigger signal } \\
\text { between Aggregator } \\
\text { and DSO }\end{array}$ & $\begin{array}{l}\text { Failure in supply, due } \\
\text { to: } \\
\text { - Faulted } \\
\text { communications or } \\
\text { control systems } \\
\text { between Aggregator } \\
\text { and DERs } \\
\text { - Faulted } \\
\text { communication of } \\
\text { trigger signal } \\
\text { between Aggregator } \\
\text { and DSO }\end{array}$ & $\begin{array}{l}\text { Failure in supply, due } \\
\text { to: } \\
\text { - Faulted } \\
\text { communications or } \\
\text { control systems } \\
\text { between Aggregator } \\
\text { and DERs } \\
\text { - Faulted } \\
\text { communication of } \\
\text { trigger signal } \\
\text { between Aggregator } \\
\text { and DSO }\end{array}$ & $\begin{array}{l}\text { Failure in supply, due } \\
\text { to: } \\
\text { - faulted } \\
\text { communications or } \\
\text { control systems } \\
\text { between Aggregator } \\
\text { and DERs }\end{array}$ & $\begin{array}{l}\text { Failure in supply, due } \\
\text { to: } \\
\text { - Faulted } \\
\text { communications or } \\
\text { control systems } \\
\text { between Aggregator } \\
\text { and DERs } \\
\text { - Faulted } \\
\text { communications } \\
\text { between Aggregator } \\
\text { and DSO } \\
\text { - Faulted } \\
\text { communication of } \\
\text { trigger signal } \\
\text { between Aggregator } \\
\text { and DSO }\end{array}$ & $\begin{array}{l}\text { Failure in supply, due } \\
\text { to: } \\
\text { - Faulted } \\
\text { communications or } \\
\text { control systems } \\
\text { between Aggregator } \\
\text { and DERs } \\
\text { - Faulted } \\
\text { communications } \\
\text { between Aggregator } \\
\text { and DSO } \\
\text { - Faulted } \\
\text { communication of } \\
\text { trigger signal } \\
\text { between Aggregator } \\
\text { and DSO }\end{array}$ \\
\hline 14 & $\begin{array}{l}\text { Penalty if } \\
\text { failed supply }\end{array}$ & $\begin{array}{l}-10,000 \text { DKK / per } \\
\text { failed delivery within } \\
\text { quality limits } \\
-4 \text { times of failed } \\
\text { delivery } \\
\rightarrow \text { termination of } \\
\text { the contract }\end{array}$ & $\begin{array}{l}-10,000 \text { DKK / per } \\
\text { failed delivery within } \\
\text { quality limits } \\
-4 \text { times of failed } \\
\text { delivery } \\
\rightarrow \text { termination of } \\
\text { the contract }\end{array}$ & $\begin{array}{l}-20,000 \text { DKK on 1st } \\
\text { failure in delivery } \\
\text { within quality limits } \\
-2 \text { times of failed } \\
\text { delivery } \\
\rightarrow \text { termination of } \\
\text { the contract }\end{array}$ & $\begin{array}{l}\text { - } 15,000 \text { DKK on 1st } \\
\text { failure in delivery } \\
\text { within quality limits } \\
-25,000 \text { DKK on } 1 \text { st } \\
\text { failure in delivery } \\
\text { within quality limits } \\
-3 \text { times of failed } \\
\text { delivery } \\
\rightarrow \text { termination of } \\
\text { the contract }\end{array}$ & $\begin{array}{l}-10,000 \text { DKK / per } \\
\text { failed delivery within } \\
\text { quality limits } \\
-4 \text { times of failed } \\
\text { delivery } \\
\rightarrow \quad \text { termination of } \\
\text { the contract } \\
\text { (Average value of } \\
\text { life-time reduction of } \\
\text { components etc. }+ \\
\text { administration }+ \\
\text { mobile power plants) }\end{array}$ & $\begin{array}{l}-15,000 \text { DKK on } 1 \mathrm{st} \\
\text { failure in delivery } \\
\text { within quality limits } \\
-25,000 \text { DKK on } 2 \mathrm{nc} \\
\text { failure in delivery } \\
\text { within quality limits } \\
-3 \text { times of failed } \\
\text { delivery } \\
\rightarrow \text { termination of } \\
\text { the contract }\end{array}$ & $\begin{array}{l}-10,000 \text { DKK on 1st } \\
\text { failure in delivery } \\
\text { within quality limits } \\
-15,000 \text { DKK on } 2 \mathrm{nc} \\
\text { failure in delivery } \\
\text { within quality limits } \\
-3 \text { times of failed } \\
\text { delivery } \\
\rightarrow \text { termination of } \\
\text { the contract }\end{array}$ \\
\hline 15 & Other & & & & $\begin{array}{l}\text { Reference signal: } \\
\text { DSO will } \\
\text { continuously (every } \\
30 . \text { sec.) send a } \\
\text { reference signal to } \\
\text { the Aggregator } \\
\text { during every event. }\end{array}$ & & $\begin{array}{l}\text { DSO will } \\
\text { continuously (every } \\
30 \text { sec.) send a } \\
\text { reference signal to } \\
\text { the Aggregator } \\
\text { during every event. }\end{array}$ & \\
\hline
\end{tabular}

\section{CONCLUSION}

An Aggregator-based Flex-market is proposed to enhance the small scale DERs to participate in flexibility services trading, which will satisfy the DSOs' requirements of congestion managements. The typically defined flexibility services i.e. PowerCut Planned, PowerCut Urgent, PowerReserve, PowerCap, PowerMax, VoltageSupport, VarSupport are analyzed and described exhaustively with a sample application. In addition, the Flex-market trading setups and processes composed with the proposed notion FLECH are also introduced in this paper. Furthermore, the demonstration architecture of the Flex-market is also depicted briefly, conducive to test the feasibility and robustness of the market solutions in the near future. The proposed Flex-market shows its superiority to facilitate the integration of DERs into power system, and the flexibility services have the potential to be a sort of novel ancillary service as well, which will contribute to improve the security and stability of distribution grid even transmission grid.

\section{ACKNOWLEDGMENT}

The authors gratefully acknowledge the financial supports and the strategic platform for innovation \& research provided by Danish national project iPower.

\section{REFERENCES}

[1] K. Trangbaek, M. Petersen, J. Bendtsen, J. Stoustrup, "Exact Power Constraints in Smart Grid Control", Proc.of the 50th IEE Conference on Decission and Control and European Control Conf., Orlando, 2011.

[2] D. V. Tackie, P. J. Douglas, H. H. Holm-Hansen, H. W. Bindner, O. Samuelson and B. H. Segerberg, "Ensuring Sufficient capacity using Smart Grid solutions", iPower WP3.1, report, Copenhagen, 2012.

[3] Energinet.dk, "Teknisk Forskrift: TF 2.1.3 Dansk MVAr-ordning", Energinet.dk, 2010

[4] H. Jóhannsson, H. Hansen, L. H. Hansen, H.-H. Holm-Hansen, P. D. Cajar, H. Bindner og O. Samuelsson, "Coordination of System needs and provision of Services", CIRED International Electricity Conference \& Exhibition, Stokholm, 2013.

[5] G. Romanovsky, G. Xydis and J. Mutale, "Participation of Smaller Size Renewable Generation in the Electricity Market Trade in UK: Analyses and Approaches", Proc.of IEEE Conference on. Innovative smart grid technologies (Europe), Manchester, 2011.

[6] The Danish Energy Authority, "Danish climate and energy policy", available at http://www.ens.dk/en-US/policy/danish-climate-andenergypolicy/Sider/danish-climate-and-energy-policy.aspx.

[7] E. Mashhour, and S. M. Moghaddas-Tafreshi, "Bidding Strategy of Virtual Power Plant for Participating in Energy and Spinning Reserve Markets-Part I: Problem Formulation", IEEE Trans. Power Systems, vol. 26, pp.949-956, May. 2011.

[8] M. Peik-Herfeh, H. Seifi, and M. K. Sheikh-El-Eslami, "Decision making of a virtual power plant under uncertainties for bidding in a day-ahead market using point estimate method", Int Journal of Electrical Power and Energy Systems, vol. 44, pp. 88-98, Aug. 2012. 